Article

\title{
Participatory Urban Planning: What Would Make Planners Trust the Citizens?
}

\author{
Joachim Åström \\ School of Humanities, Education and Social Sciences, Örebro University, 70182 Örebro, Sweden; \\ E-Mail: joachim.astrom@oru.se
}

Submitted: 15 March 2020 | Accepted: 14 May 2020 | Published: 26 June 2020

\begin{abstract}
Based on the critical stance of citizens towards urban planning, growing attention has been directed towards new forms of citizen participation. A key expectation is that advanced digital technologies will reconnect citizens and decision makers and enhance trust in planning. However, empirical evidence suggests participation by itself does not foster trust, and many scholars refer to a general weakness of these initiatives to deliver the expected outcomes. Considering that trust is reciprocal, this article will switch focus and concentrate on planners' attitudes towards citizens. Do urban planners generally think that citizens are trustworthy? Even though studies show that public officials are more trusting than people in general, it is possible that they do not trust citizens when interacting with government. However, empirical evidence is scarce. While there is plenty of research on citizens' trust in government, public officials trust in citizens has received little scholarly attention. To address this gap, we will draw on a survey targeted to a representative sample of public managers in Swedish local government $(\mathrm{N}=1430)$. First, urban planners will be compared with other public officials when it comes to their level of trust toward citizens' ability, integrity and benevolence. In order to understand variations in trust, a set of institutional factors will thereafter be tested, along with more commonly used individual factors. In light of the empirical findings, the final section of the article returns to the idea of e-participation as a trust-building strategy. What would make planners trust the citizens in participatory urban planning?
\end{abstract}

\section{Keywords}

citizen participation; e-participation; new urban agenda; planning practice; smart cities; trust in planning; urban planners

\section{Issue}

This article is part of the issue "Visual Communication in Urban Design and Planning: The Impact of Mediatisation(s) on the Construction of Urban Futures" edited by Gabriela Christmann (Leibniz Institute for Research on Society and Space, Germany), Christoph Bernhardt (Leibniz Institute for Research on Society and Space, Germany) and Jörg Stollmann (TU Berlin, Germany).

(C) 2020 by the author; licensee Cogitatio (Lisbon, Portugal). This article is licensed under a Creative Commons Attribution 4.0 International License (CC BY).

\section{Introduction}

Urban planning needs to undertake a process of transformative change to foster economic growth, social cohesion and environmental protection in line with sustainable development goals (United Nations, 2015). This will require, among other things, public support and trust. The problem is that the politics of today is characterized by a general lack of trust and, according to Swain and Tait (2007), there is a specific 'crisis of trust' in planning. Contemporary planning is identified as mistrusted for its bureaucratic nature, its incapacity to understand and work for citizens, and its bias towards business interests (Tait \& Hansen, 2007).

In the pursuit of trust, new forms of participation proliferate in urban governance. Democratic innovations (Smith, 2009), co-production of services (Alford, 2009), and participatory planning (Innes \& Booher, 2004) all represent popular initiatives for promoting direct citizen participation in policy-making. With help of new information and communication technologies, the methodological quality of these initiatives has improved significantly 
over recent years, which has made the enthusiasts believe that they now have the means of rebooting democracy, creating at least a partial antidote to illiberal populism, and increase trust in government.

Recent empirical evidence suggests participation has the ability to restore citizens' trust (Wang \& van Wart, 2007). If citizens have positive experiences with participation, they seem to increase their trust in government. However, the argument that participation leads to trust assumes that participation is effective and satisfying, which is still rarely the case. More often than not, process dissatisfaction seems to feed vicious (instead of virtuous) circles of trust (Åström \& Grönlund, 2012; Åström, Jonsson, \& Karlsson, 2017).

Citizen participation is more than technology and methodology. Success is highly dependent on the attitudes of public officials (Liao \& Schachter, 2018; Moynihan, 2003). Most public officials support the principle of participation, but it is less clear to what extent they are willing to risk experiencing negative outcomes in reality. As all forms of collaborative governance, new forms of participation include risk-taking and therefore depend on mutual trust between collaborating actors. Plenty of research has investigated trust from the standpoint of citizens, aiming to explain citizens' trust in government. Yet, very few scholars have explicitly studied how public officials think about the relationship with the public, the extent to which they trust citizens, and why (Moyson, van de Walle, \& Groeneveld, 2016; Yang, 2005). If "trust begets trust, while distrust begets distrust" (Levi, 1998), this is a serious lacuna.

The aim of this article is to expand knowledge about urban planners' trust in citizens: Do they think that citizens are trustworthy? What individual and institutional factors influence their trust in citizens? What would make planners trust the citizens in participatory urban planning? To date, empirical research has primarily emphasized individual micro-determinants of public officials' trust-perceptions. These include personality traits and the general propensity to trust other people. As the review of Moyson et al. (2016, p. 15) shows, institutional determinants of public officials' trust have yet to be systematically examined. We will take institutional theories of trust as a point of departure and test how institutional factors shapes urban planners' trust in citizens.

This article utilizes a survey that targeted a representative sample of public managers in Swedish local government $(N=1430)$. The first section presents the theoretical framework, which ends with two hypotheses related to public managers' trust in citizens. After having introduced the research context and the data, the article continues with the empirical analysis. First, we compare urban planners with other public officials when it comes to their level of trust toward citizens' ability, integrity and benevolence. In order to understand variations in trust we subsequently test a set of institutional factors, along with the more commonly used individual factors. In light of the empirical findings, the final section of the article returns to the idea of e-participation as a trust-building strategy. What would make planners trust citizens in participatory urban planning?

\section{Trust in (and by) Urban Planning}

Lack of trust in government institutions has become an increasingly discussed issue in both popular and academic literature. The activity of planning is no exception. Contemporary planning is identified as mistrusted for its bureaucratic nature, its incapacity to understand and work for citizens, and its bias towards business interests (Tait \& Hansen, 2007). In citizen evaluations of various policy areas in Swedish local government, planning ends up last. Only four out of ten Swedes are satisfied with how urban planning is conducted (Holmberg, 2018).

According to Tait and Hansen (2007), the practice of planning is particularly demanding in terms of trust. This is because planning, on the one hand, is framed as working for the public interest. Common good is a central principle in planning theory and a key justification of planning. On the other hand, planning is an inherently political activity, deciding "who gets what, when, how" (Lasswell, 1936) among a plurality of competing interests. Planning, therefore, often generates disputed outcomes that are criticized from various groups. In recent years, there has been an increasing critique aimed at the 'technical expert' because experts, as planners, have defined the public interest by applying preferred planning principles. However, in promoting particular principles as if they were universal values, planners must elevate some values while downgrading others. As the boundaries between technical knowledge and political values are often blurry, the idea of technical expertise is increasingly questioned. Does planning actually work for the common interest? Should we actually trust planners?

Against the backdrop of this kind of critique, attention has shifted from public interest as a substance to public interest as a process (Dzur, 2008). If planners cannot define the public interest themselves, perhaps they should focus on helping citizens to search it out instead? New information and communication technologies has made this much easier in recent years by enabling new forms of communication and by making information gathering much easier, without the physical limitations of place and time. E-participation is often a digital version of pre-existing practices, such as e-voting and e-petitioning. However, it also opens up truly innovative ways of engaging in urban planning, such as in collaborative mapping and placebased participation, where a combination of mobile technologies and geographical information systems are used (Le Blanc, 2020). Besides from making voice possible for more people, tools to visualize ideas, proposals and realtime changes in indicator metrics can help making citizen participation both more informed and meaningful (Salter, Campbell, Journeay, \& Sheppard, 2009).

While new forms of participation proliferate in urban governance, government perceptions of e-participation 
are difficult to evaluate (Åström, 2019; Åström, Granberg, \& Khakee, 2011). Usually there is a gap between policy intentions, including ideological arguments of participatory planning, and actual initiatives, speaking the language of more limited modernization. This gap was debated in relation to the participatory movement in the 1960s (Arnstein, 1969), and is highly debated also in relation to the New Urban Agenda of 2016. While the New Urban agenda put a lot of emphasis on Smart City initiatives and citizen participation, there has been a lot of criticism of government and corporate interests in delivering e-services and new opportunities for participation (Cardullo \& Kitchin, 2019; Shelton \& Lodato, 2019). Also, this has been accompanied by empirical analyses showing that e-participation initiatives have usually failed to deliver expected benefits (Le Blanc, 2020).

Considering recent developments in innovative tools, the main barriers for effective e-participation can hardly be looked for in the lack of advanced technology (Falco \& Kleinhans, 2018; Royo, Pina, \& Garcia-Rayaldo, 2020). A combination of institutional and individual factors is probably more important for the success and failure of e-participation initiatives. At this interface, this article will specifically look into role of planners' trust in citizens. According to Senecah (2004), trust is overwhelmingly the most commonly identified missing element in participatory processes. Plenty of research has studied trust from the standpoint of citizens, aiming at explaining citizens' trust in government and how citizen participate in politics. Yet, very few scholars have explicitly studied how public officials think about their relationship with the public. As is the case for all forms of collaborative governance, however, participatory planning is dependent on mutual trust between the collaborating actors. The introduction of new forms of participation not only requires active citizens, but also an openness to citizens' initiatives and suggestions. Trust by public officials, not only in public officials, influence the outcome (van de Walle \& Lahat, 2017).

Examining how public officials' trust in citizens vary is a surprisingly recent phenomenon that has been limited to a small group of researchers. In a ground-breaking study, Yang (2005) built a model to explain public officials' trust in citizens. Drawing on a survey of 320 public officials, he found that the general propensity to trust is a critical factor explaining officials' trust in citizens. This result was more or less confirmed by Vigoda-Gadot, Zalmanovitch, and Belonogov (2012) as well as by Lee and $\mathrm{Yu}$ (2013). While other individual factors have been tested, such as gender and age, "most studies fail to detect any effect of officials' individual characteristics on their trust towards citizens" (Moyson et al., 2016). Thus, the general idea seems to be that trust in citizens is embedded in officials' general propensity to trust others.

\section{Institution-Based Trust}

The division between micro- and macro-sources of trust has been around for a long time in organizational trust re- search. Yet, Bachmann argues that most studies consider trust to be micro-level phenomenon created by contacts between individuals (Bachmann, 2011). Usually trust is theorized as a psychological phenomenon, while macrolevel factors, like institutions, are considered less important. In contrast to this de-contextualized understanding of trust, Bachmann argues that "institutional-based trust, i.e., trust that constitutively builds on institutional arrangements, deserves more attention than is currently granted by large parts of the trust literature" (Bachmann, 2011, p. 206).

While trust is a relational phenomenon, institutional theories of trust emphasize that relations between individuals develop in particular contexts where the level of environmental uncertainty influence trust building. In other words, planners trust in citizen is likely to depend on the prevailing institutional arrangements and structures that underlie urban planning. One way in which institutional factors may facilitate planners' trust in citizens is by reducing the risk of the planner, making it easier for him to grant trust to citizens. Besides, public officials may trust citizens because they identify with a common political institutional space which makes most citizens worthy of being trusted. In either case, political institutions have "a formative function" (Offe, 1999).

There have been a few attempts to link public officials' trust in citizens to various institutional factors. Vigoda-Gadot et al. (2012), for instance, showed that perceptions of citizens' trustworthiness are linked to perceptions of 'organizational politics.' Officials considering their colleagues to be self-serving and self-interested, at the expense of other colleagues and the organization as a unit, tend to trust citizens less. That trust is held because of structural relations is also indicated by Ivacko, Horner, and Crawford (2013), who showed that public officials working in city and township administrations are more likely to trust citizens than those working in village or county administrations. While manifesting itself in interpersonal relationships, this suggests that trust in citizens is related to institutional factors.

Twenty years of e-participation research have shown the critical importance of having a strong connection between participatory initiatives and decision-making bodies. When citizens feel that e-participation processes are disconnected from decision-making, the result is often a decreasing trust in public institutions (Le Blanc, 2020). For urban planners, with the task to structure public participation and channel public demands into decisions, decision-making arrangements is a key institutional context. In the public administration literature, few questions are as vexed and enduring as the relationship between politics and administration within policy-making. In this article we will therefore empirically explore two aspects of politico-administrative relations and their relationship to planners trust in citizens. The first is political power. The second is political trust.

Political power can be seen as an instrument for reducing uncertainty. If planners have a great deal of polit- 
ical power, we may therefore expect that this will spill over into their attitudes towards citizens in a positive way. Powerful planners are more in control and can probably better protect themselves if trust in citizens is misplaced. By contrast, planners who lack power may not always afford trusting the citizens and risk the negative consequences that may follow. For similar reasons it is probably important for planners to trust their politicians to stick to what they have communicated and prioritized, as well as to refrain from blame and responsibility avoiding behavior (Grön \& Salomonsen, 2019). For these reasons, we suggest that political trust is positively related to trust in citizens.

Other institutional factors that may reduce the risk for planners, which we will put to an empirical test, is trust in institutions and administrative capacity. Just, accountable and effective institutions may shield from risk and reduce uncertainty (Levi, 1998), and administrative capacity is important for effective policy implementation. Costly citizen participation processes may pull resources away from the planning mission and reduce onthe-ground results, while poor performance may backfire and create more distrust towards government. The availability of resources needed to engage with citizens is therefore expected to reduce risk and increase trust in citizens. Two overarching hypotheses are tested:

1. Institutional factors are significantly associated with planners' trust in citizens when individual factors are controlled for.

2. Institutional factors that increase the degree of environmental certainty, such as power, capacity and political and institutional trust, are positively related to trust in citizens.

\section{Data and Measurements}

\subsection{Data}

Public managers are largely responsible for designing, implementing, and making use of the results, and so they largely determine the outcome of government initiated participatory processes (Liao \& Schachter, 2018; Moynihan, 2003). In Swedish local government, there are about 31,000 public managers. To examine their attitudes towards citizens, a random sample of 3,000 individuals - registered as managers and employed by a Swedish local government-was made from the occupation register. Statistics Sweden made the sample and facilitated the data collection by way of a broad survey in 2018. The survey included questions and statements related to 25 themes in which one theme measured public official's perceived trust in citizens. The response rate to the survey reached $48 \%$ (1,430 responses).

Among the 1,430 public managers in the data base, $32 \%$ are men and $68 \%$ are women, which illustrates the major changes that have taken place during last couple of decades when it comes to leadership and gen- der in Swedish local government (Johansson, Lindgren, $\&$ Montin, 2018). Not long ago, these numbers were reversed. About half of the respondents were 55 years of age or older and the non-response analysis revealed an underrepresentation of managers under the age of 35 (response rate of $24 \%$ ). Most importantly for this study, 80 respondents (or $6 \%$ ) were city planning managers. The other managers included school managers (29\%), preschool managers (15\%), elderly care managers (15\%), social work managers (18\%), managers at technical departments ( $8 \%)$ and central administration (9\%). The relatively small number of city planning managers is a limitation of the study, which reduces the statistical power of our tests. Large samples tend to give more reliable results, while small samples often leave the null hypothesis unchallenged.

\subsection{Measurements}

Regardless of the underlying perspective (micro or macro), 'confident expectations' and 'a willingness to be vulnerable' are important aspects of definitions of trust. According to Rousseau, Sitkin, Burt, and Camerer (1998, p. 395), "trust is a psychological state comprising the intention to accept vulnerability based upon positive expectations of another." Following Yang (2005), this article sees 'trust' as based perceptions of competence, benevolence and integrity. Competence refers to skills and competencies that enable citizens to have influence within a specific domain. Benevolence and integrity take up the intentions of the trustee; the intention to do good to the trustor, aside from egoistic motives.

The dependent variable was measured via six items, which were assessed with the question: Citizens I interact within my work are generally: (1) reliable, (2) sincere and honest in their contacts with the local government, (3) well aware of local government affairs and current issues, (4) knowledgeable of how the local government organization works, (5) committed to change and improve the municipality, and (6) more concerned about what benefits the municipality as a whole, than what benefits them personally. The Likert-type scale varied between 0 (strongly disagree) to 3 (strongly agree). Cronbach's alpha was .748, which is an acceptable level of reliability of this measure as a dependent variable. All measurements used are summarized in Table 1.

\section{Empirical Results}

\subsection{Planners' Trust in Citizens}

Empirical research indicates public officials strongly support the idea of citizen participation in the abstract. However, it also indicates their orientations in practice are less attuned to abstract normative goals than to concerns with concrete instrumental costs and benefits (Åström \& Granberg, 2007; Liao \& Schachter, 2018). Potential benefits include making the work of govern- 
Table 1. Operationalization and measurements.

\begin{tabular}{|c|c|c|c|}
\hline Concept & Operationalization & Variable & Scale \\
\hline Trust in citizens & $\begin{array}{l}\text { Assesses how the respondents } \\
\text { perceive citizen's integrity, } \\
\text { knowledge and benevolence }\end{array}$ & $\begin{array}{l}\text { Additive Index based on six items. } \\
\text { Scales ranging from } 0 \text { (strongly } \\
\text { disagree) to } 3 \text { (strongly agree) }\end{array}$ & $\begin{array}{l}0-18 \\
\alpha: .748\end{array}$ \\
\hline Social trust & $\begin{array}{l}\text { Measures the extent to which } \\
\text { respondents think that "most } \\
\text { people can be trusted" }\end{array}$ & $\begin{array}{l}\text { Single item. Scale ranged from } 0 \text { (do } \\
\text { not agree) to } 3 \text { (strongly agree) }\end{array}$ & $0-3$ \\
\hline Trust in institutions & $\begin{array}{l}\text { Measures the respondents degree } \\
\text { of trust in the Police, Courts, } \\
\text { Government, Local governments, } \\
\text { Parliament, Local councils, Health } \\
\text { care, Political parties, School, Press, } \\
\text { EU-commission, Universities, County } \\
\text { Administrative Boards }\end{array}$ & $\begin{array}{l}\text { Additive index based on } 13 \text { items. } \\
\text { Scales ranging from } 0 \text { (strongly } \\
\text { disagree) to } 4 \text { (strongly agree) }\end{array}$ & $\begin{array}{l}0-52 \\
\alpha: .875\end{array}$ \\
\hline Political trust & $\begin{array}{l}\text { Assesses the respondents view of } \\
\text { local politicians and parties }\end{array}$ & $\begin{array}{l}\text { Additive index based on four items. } \\
\text { Scales ranging from } 0 \text { (do not agree) } \\
\text { to } 3 \text { (strongly agree) }\end{array}$ & $\begin{array}{l}0-12 \\
\alpha: .751\end{array}$ \\
\hline Administrative capacity & $\begin{array}{l}\text { Assesses the respondents view of } \\
\text { workplace conditions }\end{array}$ & $\begin{array}{l}\text { Index variable based on } 11 \text { items. } \\
\text { Scales ranging from } 0 \text { (do not agree) } \\
\text { to } 3 \text { (strongly agree) }\end{array}$ & $\begin{array}{l}0-33 \\
\alpha: .822\end{array}$ \\
\hline Power & $\begin{array}{l}\text { Self-reported measure of the } \\
\text { respondents' power in local } \\
\text { government }\end{array}$ & $\begin{array}{l}\text { Single item. Scale ranged from } 0 \text { (very } \\
\text { weak) to } 5 \text { (very strong) }\end{array}$ & $0-5$ \\
\hline
\end{tabular}

ment more acceptable to citizens and promoting more effective decision-making. Potential risks and uncertainties are associated with time, money, and other resources that can be used otherwise, and also with the possibility that citizen participation may exacerbate conflicts or result in undue influence of uninformed individuals and become ineffective for such reasons. For the implementation of participatory planning, this implies that lower degrees of trust in citizens may lead to reduced risk-taking, less involvement and less citizen con- trol. Correspondingly, higher degrees of trust should be expected to increase risk-taking and motivate steps up "the ladder of participation" (Arnstein, 1969).

In order to understand these dynamics, we need to explore planners' and other public officials' trust in citizens. To what extent do planners and other public officials trust citizens? Table 2 compares city planning managers with other managers when it comes to their level of trust towards citizens' integrity, ability and benevolence. Their perception of integrity, measured by the per-

Table 2. Public managers' trust in citizens (percentages that agree).

$\begin{array}{ccc}\begin{array}{c}\text { City planning } \\ \text { managers }\end{array} & \text { All other } & \\ (n=76-79) & \text { managers } & \text { Cramer's V } \\ \end{array}$

Citizens I interact with in my work are generally:

1. Reliable

82

2. Sincere and honest in their contacts with the local government

3. Well aware of local government affairs and current issues

4. Knowledgeable of how the local government organization works

5. Committed to change and improving the municipality

6. More concerned about what benefits the municipality as a whole than what benefits them personally

Trust in citizens index (high)
79

$\begin{array}{lll}82 & 83 & .004 \\ 79 & 79 & .005 \\ 49 & 39 & .048 \\ 22 & 21 & .002 \\ 62 & 45 & .076^{*} \\ 13 & 16 & .021\end{array}$

50

48

.009

Notes: $\mathrm{N}=1359-1381$; Scale ranged between 0 (strongly disagree) to 3 (strongly agree). Cramer's $\mathrm{V}$ used for percentages that agree. 
ception that citizens are reliable, sincere and honest in their contacts with the local government, seems to be high. About eight out of ten city managers agree that citizens have integrity. In relation to ability and benevolence, fewer respondents were positive. Among the city planning managers, less than half agree that citizens are aware of local government affairs and current issues, and less than one in four agree that citizens are knowledgeable of how the local government organization works. In relation to benevolence, more than half agree that citizens are committed to change and improve the municipality, but only $13 \%$ think that they are more concerned with what benefits the municipality as a whole than what benefits them personally.

The results presented above are interesting if we consider that public officials' social trust is usually very high, especially in high-trusting countries like Sweden. As van de Walle and Lahat (2017) show, public officials generally have more social trust than non-public officials, and the public officials in Sweden are among the most trusting in Europe. Clearly, our results signal a less encouraging picture. Even though public officials are more trusting than people in general, the results indicate that far from everyone trusts citizens when interacting with government.

Arguments against citizen participation (Irvin \& Stansbury, 2004) often state that citizens are not qualified to participate directly in policy-making, because they lack commitment and competence or because they are merely looking after their own shortsighted interests instead of long-term community interests. Accordingly, planners who believe that the public lacks the ability to understand their actions and current issues are probably less enthusiastic to hear the public's thoughts. Planners who believe that the public care more about themselves than their community can likewise be expected to have a decreased willingness to make themselves vulnerable to the public.

In relation to the debate over the specific crisis of trust in planning (Swain \& Tait, 2007), it is also interesting to note that city planning managers do not trust citizens less than other public managers. There is no statistically significant difference between planners and other pub- lic managers, except when it comes to the perception of citizens' commitment to change and improve the municipality (which is higher). However, this does not mean the institutional context is unimportant.

\subsection{Explaining Variations in Trust}

Is it that public managers' trust in citizens mainly reflect their social trust? Or, are institutional factors more important for understanding managers' propensity to trust citizens? In order to test the effects of the selected variables, we specify four models. Besides from separating city planning managers and all managers, two of the models (1 and 3 ) only estimates the effect of social trust, while models 2 and 4 also includes the institutional factors.

In Table 3, our models on all managers' (3 and 4) show that institutional factors have a significant effect on trust in citizens and that this effect is stronger than social trust. While previous studies indicate that trust in citizens is part of an individual's general willingness to trust others, the results indicate that this is so only as long as institutional factors are not taken into consideration. Furthermore, Table 3 shows that all institutional factors have significant effects on trust in citizens. Returning to the underlying expectations outlined in the previous sections, it appears reasonable to conclude that the assumptions are largely being met by our data. The institutional context matters for public managers' trust in citizens.

Our models on city planning managers show a similar pattern, even if we cannot be quite as sure that the relationships in our sample also exist in the larger population of city planning managers. Only one variable is statistically significant in model 2: political trust. Given the generalizable results in model 4 , there is however little reason not to believe that power, institutional trust and the assessments of administrative capacity also play a role for planners. Our models on city planning managers rather indicates that the overall effects of the institutional factors are stronger among the planners than all managers.

The variables that have the highest impact on trust in citizens in our models are political trust and political

Table 3. Explaining public managers' trust in citizens (standardized Beta).

\begin{tabular}{lcccc}
\hline & \multicolumn{2}{c}{ City planning managers } & \multicolumn{2}{c}{ All managers } \\
\cline { 2 - 5 } & Model 1 & Model 2 & Model 3 & Model 4 \\
\hline Social trust & .204 & -.067 & $.145^{* * *}$ & .020 \\
Institutional trust & - & .124 & - & $.116^{* * *}$ \\
Capacity & - & .153 & - & $.106^{* * *}$ \\
Political trust & - & $.371^{* *}$ & - & $.144^{* * *}$ \\
Political Power & - & .200 & - & $.158^{* * *}$ \\
City planning (dummy) & - & - & .015 \\
$\mathrm{~N}$ & 75 & .278 & .019 & 1187 \\
R2 (Adjusted) & .030 & .130 & .130 \\
\hline
\end{tabular}

Note: Hidden controls for gender, age and municipality size. 


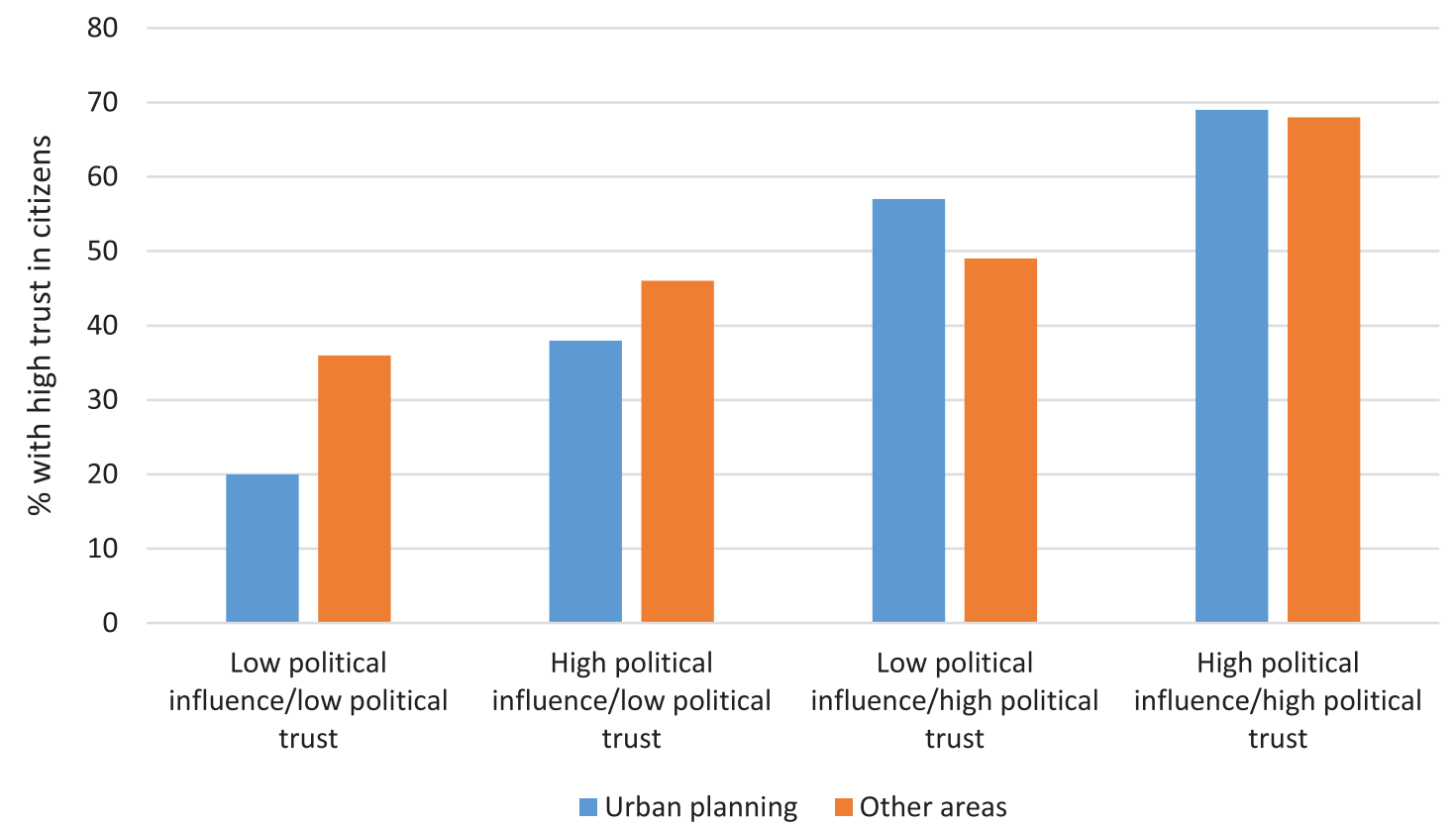

Figure 1. Politico-administrative relations and trust in citizens (percentage high trust in citizens). Source: Own survey results.

power. The more power public managers' understand they have, the more they tend to trust citizens integrity, competence and benevolence. The degree to which public managers trust politicians also affects their trust in citizens. The results underline the overall prominence of politico-administrative relations for trust in citizens. Trust suggests a vulnerability to citizens, which depends on power relations. For city planners, "positioned at the nexus of public and private interests" (Laurian, 2009, p. 369) and highly involved in politics, the relationship with politicians seems to be particularly important.

\subsection{Politico-Administrative Relations and Trust in Citizens}

How elected politicians and public managers relate and should relate to each other is an old debate in political science and public administration. Policy content and the legitimacy of policy-making is affected by the relative influence of politicians and managers. Compared to other managers, city planning managers are more influential in local politics. While the other independent variable we have tested do not vary between the two groups, there is a statistically significant difference when it comes to self-reported power. At the same time our results indicate that political trust is one of the strongest predictors of trust in citizens, and particularly strong amongst the planners. Against this background, the relationship between the two political variables deserves a closer look.

In terms of the relationship between employer, employee and customer, empirical research suggests that employees treat customers as they themselves have been treated by their organization (Payne \& Frow, 2005). This is comparable to what we have found and described here. A linear trend arises in both groups, indicating that more power and political trust increases trust in citizens. When managers have a high level of political influence and political trust, this seems to spill over in their attitudes towards citizens.

As Figure 1 shows, there is a small tendency that trust matters more for planners than for other managers. The red staple is higher than the blue when political trust is low, and the blue is higher than the red when political trust is high. Given the political nature of planning (Tait \& Hansen, 2007), city planning managers are an integral part of strategic policy-making and perhaps more dependent on cooperative, trustful relationship with politicians. When public managers gain political influence, they enter the political domain, creating a gray zone between the two. This is what Svara (2006) points out when conceptualizing the relationship between politics and administration as one of complementarity. The essence of a such a relationship is risk-taking by both sides, and thus that public managers become more vulnerable for criticism and blame.

\section{Conclusion}

Even though public officials are more trusting than people in general, this study shows that far from everyone trust citizens when interacting with government. As Newman, Barnes, Sullivan, and Knops (2004) reminds us, new forms of participation do not displace old forms of governance but interact with them. This creates opposing imperatives for public managers. They should promote participation from below, but make sure to deliver on goals set from above. They should take part in longterm trust work, but also finish tasks in the short term. 
Public managers' relationship with citizens exist in an institutional milieu, where the level of uncertainty influence trust building.

According to the results in this study, planners' perceptions of the institutional context are significantly associated with trust in citizens. Power, capacity as well as political and institutional trust, are all positively related to trust in citizens. When the institutional factors were introduced in the regression analysis, the most important factor in previous research, social trust, lost its significance. When it comes to the specificity of city planning managers vis-à-vis other public managers, the results do not show an overall difference in terms of trust. However, to some extent the results confirm that urban planning is a challenging context. City planning managers perceive themselves as more powerful than other managers, and their trust in citizen seem somewhat more dependent upon their trust in politicians, even though we should be careful drawing too strong conclusions based on our limited sample.

Trust and control are often conceptualized as opposing alternatives to handle risk. For instance, Reed (2001) argues that trust and control are "most usefully conceptualized as analytically distinctive but, but mutually conditioning, elements" (Reed, 2001, p. 202). When public managers have little trust in citizen's integrity, knowledge and benevolence, it is reasonable to think they are taking greater control over the process and makes themselves less vulnerable to citizens. There are plenty of examples of this in the literature. One typical example is that issues containing conflicting interests are avoided, while citizens are instead invited to participate in non-conflictual and non-political issues. It is also common that participatory processes are disconnected from decision-makers, and that the lack of a facilitating institutional landscape hampers their capacity to influence policy. Analyzed from the perspective of Arnstein's (1969) influential "ladder of citizen participation," many of these initiatives are seen as symbolic. As such, they do not share power and they do not build trust in planning.

Smart city initiatives and e-participation are today highly prioritized by city managers and technology companies who are implementing the New Urban Agenda. However, to reap the benefits of smart cities a virtuous loop of participation and trust is necessary. While smart cities hold forth intelligent and highly developed services to citizens, they come at a cost. To realize 'smartness,' large volumes of citizen data must be stored, processed and analyzed. Internet of Things and big data hereby brings vulnerabilities in smart city services, which will demand a great deal of trust by citizens. If citizens do not feel part of these changes, technology can feel imposed rather than inclusive.

According to the critics, too much effort has been directed towards technology in the implementation of smart city initiatives while the participatory element, or even the human element, is largely missing (Levenda, Keough, Rock, \& Miller, 2019; Shelton \& Lodato, 2019).
The smart city has been shaped by providers of big technology and by the mindset of top-down master planning, it is argued. In response to such criticism, some scholars have tried to turn the discussion of 'smartness' from one of 'smart cities' to that of 'smart citizens.' Their recipe is about empowering citizens while using smart technologies and e-participation tools, which would demand a great deal of trust by planners in citizens.

New e-participation tools for visualizing and influencing urban futures will meet a variety of citizens with diverse resources and different motivations. Some citizens are likely to stay passive, regardless of the participatory initiative taken, whereas others are potentially easier groups to engage. Yet, it is interesting to note that there is research indicating that e-participation may attract other citizens than the usual suspects. For instance, Åström et al. (2017, p. 584) show that e-participation tends to "attract some of those with weak connections to formal politics and who feel there is a discrepancy between how democracy should work and how it actually works." This raises a hope that e-participation actually can bring critical citizens back in and increase trust in planning. Yet, the analysis also shows that citizens with a negative predisposition towards planning are more sensitive to any signs of distrust of planner's vis-à-vis citizens; that distrust is easily reinforced.

A number of interrelated trends are thus making trust more important than ever, as well as more challenging in some ways. In relation to Smart City initiatives and the New Urban Agenda this raises a question about what can be done: What can the actors do to enable trust-building? According to institutional theories, the key to stimulating trust-without falling into blind, naïve, misplaced trust-is to employ suitable institutional arrangements or 'safeguards' that help reduce uncertainty among the actors. New forms of participation provide a great opportunity for experimenting with such trust-building arrangements. However, in the past, research and development activities have typically had a one-sided focus, trying to find mechanisms that close the political distance between citizens and governments. This study reveals that we need to also aim for institutional arrangements that close the distance between politics and public administration. When the perceived distance between politics and administration is less, public managers' trust in citizens is greater. When the perceived distance is greater, there is less trust in citizens. Therefore, creating institutional arrangements in which tensions and differences between managers and politicians are handled in a constructive manner is key for any initiative towards participatory planning.

\section{Acknowledgments}

The author would like to thank the participants at the 2019 conference "Visual Communication In Urban Design And Planning," Berlin, for their insightful and very helpful comments on earlier versions. He also thanks the 
referees and editors of Urban Planning for their very constructive comments.

\section{Conflict of Interests}

The author declares no conflict of interests.

\section{References}

Alford, J. (2009). Engaging public sector clients. From service-delivery to co-production. New York, NY: Palgrave MacMillan.

Arnstein, S. (1969). A ladder of citizen participation. Journal of the American Institute of Planners, 35(4), 216-224.

Åström, J. (2019) Citizen participation. In A. M. Orum (Ed.), The Wiley-Blackwell encyclopedia of urban and regional studies. Malden, MA: Wiley-Blackwell.

Åström, J., \& Granberg, M. (2007). Urban planners, wired for change? Understanding elite support for e-participation. Journal of Information Technology \& Politics, 4(2), 63-77.

Åström, J., Granberg, M., \& Khakee, A. (2011). Apple piespinach metaphor: Shall e-democracy make participatory planning more wholesome? Planning Practice \& Research, 26(5), 571-586.

Åström, J., \& Grönlund, ̊̊. (2012). Online consultations in local government: What works, when and how. In S. Coleman \& P. Shane (Eds.), Connecting democracy: Online consultation and the flow of political communication. Cambridge, MA: MIT Press.

Åström, J., Jonsson, M. E., \& Karlsson, M. (2017). Democratic innovations: Reinforcing or changing perceptions of trust? International Journal of Public Administration, 40(7), 575-587.

Bachmann, R. (2011). At the crossroads: Future directions in trust research. Journal of Trust Research, 1, 203-213.

Cardullo, P., \& Kitchin, R. (2019). Smart urbanism and smart citizenship: The neoliberal logic of "citizenfocused" smart cities in Europe. Environment and Planning C: Politics and Space, 37, 813-830.

Dzur, A. (2008). Democratic professionalism: Citizen participation and the reconstruction of professional ethics, identity, and practice. University Park, PA: Penn State University Press.

Falco, E., \& Kleinhans, R. (2018). Beyond technology: Identifying local government challenges for using digital platforms for citizen engagement. International Journal of Information Management, 40, 17-20.

Grön, C. H., \& Salomonsen, H. H. (2019). In the mayor we trust? Trust as the micro-foundation of complementary politico-administrative relations in local governments. Administration \& Society, 51(4), 581-606.

Holmberg, S. (2018). Offentlig verksamhet får sämre betyg [Public sector activities receive worse grades]. In U. Andersson, A. Carlander, E. Lindgren, \& M. Oskarson (Eds.), Sprickor i fasaden [Cracks in the facade].
Gothenburg: SOM Institute, Gothenburg University. Innes, J. E., \& Booher, D. E. (2004). Reframing public participation: Strategies for the 21st Century. Planning Theory \& Practice, 5(4), 419-436.

Irvin, R. A., \& Stansbury, J. (2004). Citizen participation in decision making: Is it worth the effort? Public Administration Review, 64(1), 55-65.

Ivacko, T., Horner, D., \& Crawford, M. (2013). Beyond trust in government: Government trust in citizens? SSRN Electronic Journal, 2013(January). http://dx. doi.org/10.2139/ssrn.2284413

Johansson, V., Lindgren, L., \& Montin, S. (2018). Den kommunala statliga ämbetsmannen [The municipal state public servant]. Lund: Studentlitteratur.

Lasswell, H. D. (1936). Politics: Who gets what, when, how. New York, NY: P. Smith.

Laurian, L. (2009). Trust in planning: Practical and theoretical considerations for participatory and deliberative planning. Planning Theory \& Practice, 10(3), 369-391.

Le Blanc, D. (2020). E-participation: A quick overview of recent qualitative trends. New York, NY: United Nations.

Lee, S., \& Yu, H. (2013). Factors affecting public servants' trust in citizens: A case study of South Korean Central Government officials. International Review of Public Administration, 18(3), 85-114.

Levenda, A. M., Keough, N., Rock, M., \& Miller, B. (2019). Rethinking public participation in the smart city. The Canadian Geographer/Le Géographe canadien, 2019, 1-15.

Levi, M. (1998). A state of trust. In V. Braithwaite \& M. Levi (Eds.), Trust and governance (pp. 77-101). New York, NY: Russel Sage Foundation.

Liao, Y., \& Schachter, H. L. (2018). Exploring the antecedents of municipal managers' attitudes towards citizen participation. Public Management Review, 20(9), 1287-1308.

Moynihan, D. P. (2003). Normative and instrumental perspectives on public participation. American Review of Public Administration, 32(2), 164-188.

Moyson, S., van de Walle, S., \& Groeneveld, S. (2016). What do public officials think about citizens? The role of public officials' trust and their perceptions of citizens' trustworthiness in interactive governance. In J. Edelenbos \& I. van Meerkerk (Eds.), Critical reflections on interactive governance. Self-organization and participation in public governance (pp. 189-208). Cheltenham: Edward Elgar.

Newman, J., Barnes, M., Sullivan, H., \& Knops, A. (2004). Public participation and collaborative governance. Journal of Social Policy, 33(2), 203-223.

Offe, C. (1999). How can we trust our fellow citizens? In M. E. Warren (Ed.), Democracy and trust (pp. 42-87). New York, NY: Cambridge University Press.

Payne, A., \& Frow, P. (2005). A strategic framework for customer relationship management. Journal of Marketing, 69, 167-176. 
Reed, M. (2001). Organization trust and control: A realist analysis. Organization Studies, 22(2), 201-222.

Rousseau, D. M., Sitkin, S. B., Burt, R. S., \& Camerer, C. (1998). Not so different after all: A cross-discipline view of trust. Academy of Management Review, 23(3), 393-404.

Royo, S., Pina, V., \& Garcia-Rayaldo, J. (2020). Decide Madrid: A critical analysis of an award-winning eparticipation initiative. Sustainability, 12, 1-19.

Salter, J. D., Campbell, C., Journeay, M., \& Sheppard, S. R. J. (2009). The digital workshop: Exploring the use of interactive and immersive visualisation tools in participatory planning. Journal of Environmental Management, 90, 2090-2101.

Senecah, S. L. (2004). The trinity of voice: The role of practical theory in planning and evaluating the effectiveness of environmental participatory processes. In S. W. Depoe, J. W. Delicath, \& M.-F. Aepli Elsenbeer (Eds.), Communication and public participation in environmental decision making (pp. 13-33). Albany, NY: State University of New York Press.

Shelton, T., \& Lodato, T. (2019). Actually existing smart citizens: Expertise and (non)participation in the making of the smart city. City, 23(1), 35-52.

Smith, G. (2009). Democratic innovations: Designing institutions for citizen participation. Cambridge: Cambridge University Press.
Svara, J. (2006). Politicians and administrators in the political process: A review of themes and issues in the literature. International Journal of Public Administration, 29(12), 953-976.

Swain, C., \& Tait, M. (2007). The crisis of trust and planning. Planning Theory \& Practice, 8(2), 229-247.

Tait, M., \& Hansen, C. J. (2007). Trust and governance in planning. Paper presented at the AESOP annual congress 2007, Naples, Italy.

United Nations. (2015). Transforming our word: The 2030 agenda for sustainable development. New York, NY: United Nations.

van de Walle, S., \& Lahat, L. (2017). Do public officials trust citizens? A welfare state perspective. Social Policy \& Administration, 51(7), 1450-1469.

Vigoda-Gadot, E., Zalmanovitch, Y., \& Belonogov, A. (2012). Public servants' trust in citizens: An extension of theory and an empirical examination with structural equation modeling (SEM). Public Organization Review, 12(4), 383-399.

Wang, X., \& van Wart, M. (2007). When public participation in administration leads to trust: An empirical assessment of managers' perception. Public Administration Review, 67(2), 265-278.

Yang, K. (2005). Public administrators' trust in citizens: A missing link in citizen involvement efforts. Public Administration Review, 65(3), 273-285.

\section{About the Author}

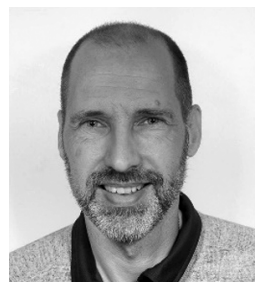

Joachim Åström is Professor of Political Science at Örebro University, Sweden. His research interests focus on democratic innovations, changing patterns of participation and institutional change. This includes various factors that facilitate or hinder the success of e-participation in smart city governance. 